\title{
Local quality work in an age of accountability - between autonomy and control
}

\section{Andreas Bergh}

To cite this article: Andreas Bergh (2015) Local quality work in an age of accountability - between autonomy and control, Journal of Education Policy, 30:4, 590-607, DOI: 10.1080/02680939.2015.1017612

To link to this article: https://doi.org/10.1080/02680939.2015.1017612

\section{(C) 2015 The Author(s). Published by Taylor \& Francis}

\section{Published online: 03 Mar 2015.}

Submit your article to this journal $\square$

\section{Џ Article views: 1096}

View Crossmark data ¿

7 Citing articles: 5 View citing articles $\square$ 


\title{
Local quality work in an age of accountability - between autonomy and control
}

\author{
Andreas Bergh ${ }^{\mathrm{a}, \mathrm{b} *, 1}$ \\ ${ }^{a}$ School of Humanities, Education and Social Sciences, Örebro University, Örebro, Sweden; \\ ${ }^{b}$ Department of Education, Uppsala University, Uppsala, Sweden
}

(Received 24 June 2014; accepted 3 February 2015)

\begin{abstract}
This article analyses a specific part of the actions taken to improve the quality of Swedish education, namely the expectations formulated in national policy documents for the quality work that local authorities, schools and teachers are supposed to undertake. For the empirical analysis of how these expectations have changed over the last two decades, two sets of theoretical concepts have been combined: management of placement and management of expectation and autonomy and control. The specific research question is: How can local systematic quality work be understood in an age of accountability and what are the implications for teachers' practices? The results show that expectations for local quality work have changed radically during the studied period. There has been a significant change in the language used, the content of education has been recontextualised and there are obvious changes in the relation between local autonomy and national control. It is argued that these changes are a consequence of the changed design of the education system, rather than an answer to a content-related question of what is educationally desirable. As a consequence, paradoxical expectations land at the local level and have to be resolved by teachers.
\end{abstract}

Keywords: quality work; autonomy; control; accountability; teacher; Sweden

\section{Introduction}

In recent decades, there has been a strong emphasis in many countries on the quality of education. One example of this is the widely spread tendency to strengthen quality assurance and evaluation policies and practices. This has been discussed in a special thematic issue of the Journal of Education Policy entitled, 'Fabricating Quality: Data and the New Governance of Education' (Journal of Education Policy 2009). Some studies have also demonstrated how the use of the quality concept has changed over time in national education policy documents. In Sweden, which is used as an empirical case in this article, an earlier understanding that education quality was best dealt by teachers has gradually been challenged and partly marginalised by an emphasis on results and relating to the market and system needs (Bergh 2010, 2011). These changes have also been discussed in terms of a shift from a quality idea to a quality regime, with consequences for the relation between local autonomy

\footnotetext{
*Emails: andreas.bergh@oru.se, andreas.bergh@edu.uu.se

${ }^{1}$ In 2014, Andreas Bergh began a two-year postdoctoral research fellowship at the Department of Education, Uppsala University, Sweden.
} 
and national control (Morawski 2010; Nytell 2006). Despite these obvious tendencies, the complexity of governing and its consequences need be further analysed. The interest in this article is therefore to analyse a specific aspect of Swedish education policy, so-called local quality work, a quality tool that was introduced by the government in 1997 for use at local level (Skr 1996/97:112).

In the new Swedish Education Act (SFS 2010:800) there is a strong emphasis on the systematic quality work that local authorities, schools and pedagogical staff are expected to undertake. At the same time, a significantly strengthened national control system has been put in place. Following the possible tensions that might arise between local autonomy and national control, the overriding purpose of the article is to analyse how expectations for local quality work expressed in Swedish education policy documents have changed over time and to discuss what these changes might mean for teachers' practices. The analysis is based on a close reading of policy texts from successive Swedish Governments and national school authorities over the last two decades, with a specific focus on the policy tool that has been developed around the concept of quality for use at local level.

Next, the Swedish case is presented, followed by an introduction of the theoretical concepts and methodological approach used for the study. Thereafter, in the empirical analysis of how expectations for local quality work have changed over time, two sets of theoretical concepts are combined: management of placement and management of expectation (Hopmann 2008) and autonomy and control (Cribb and Gewirtz 2007). Finally, in the last part of the article the specific research question is discussed, which is: How can local systematic quality work be understood in an age of accountability and what are the implications for teachers' practices?

\section{The Swedish case}

The Swedish case is of particular interest from an international perspective because within a very short period the introduction of the quality concept radically challenged and partly marginalised the earlier national education tradition (Bergh 2010). As will be demonstrated, the Swedish education reforms of recent decades can be characterised as having created an education for a system, rather than a system for education.

An important starting point for this particular study is that the development that is taking place around the quality concept in Swedish education is not limited to a single concept or a specific context. Rather, it reflects a wider social transformation that is occurring in education and in many other sectors in Sweden and in other countries. For example, in educational research questions have been asked as to whether this is the end of schooling as we know it and it has also been argued that we need to re-engage with the question of what constitutes good education (Biesta 2010; Hopmann 2013). Thus, there does not seem to be any doubt that earlier educational visions and traditions have been challenged, or even marginalised.

The similarities at international and national policy levels have been widely reported and discussed in previous research. It has been demonstrated how the formulation of international policy has reshaped national frameworks for action and that the influence of powerful organisations, such as the EU and OECD, has promoted a restructuring of the horizon of expectation for member countries and partners (Grek and Lawn 2009; Nordin 2012; Sivesind, van den Akker, and Rosenmund 2012). From national contexts, such as the UK, it is reported that globalisation has 
been discursively managed as a hegemonic project, which 'works as a way of thinking and speaking that makes possible certain ways of acting and behaving and at the same time, works to conceal other versions or alternatives' (Maguire 2002, 263). This has also been described 'as a shift in strategy that is highly dependent on the appearance of deregulation, but that is equally marked by strong central steering through various policy technologies, including curriculum control' (Ozga 2009, 150).

However, besides reports of the many similarities at international and national policy levels it is also pointed out that the formal curricula and their associated pedagogical practices remain largely under-researched as elements in the governing of education (Sivesind, van den Akker, and Rosenmund 2012). There is, thus, a need to acquire more knowledge about how international policy is shaped in relation to the national and local educational contexts. A central reason for this is that policies have to be interpreted and 'translated' by diverse policy actors, rather than simply implemented (Braun, Maguire, and Ball 2010). In the context of this study it means that national contexts, including the society's own social, political and cultural history, need to be taken into account. Here, the Swedish case is of particular interest.

On the one hand, as part of the social and cultural project of building the nation and preparing for national citizenship, the Swedish school system has a relatively long history of comprehensive education for democracy and equality (Sundberg and Wahlström 2012). In that tradition, teachers were entrusted with the authority to choose and use different means to achieve the curriculum goals. On the other hand, in recent decades this has been challenged in several different ways.

During the early 1990s, the Swedish school system became one of the most decentralised in the Western world (Lundahl 2002). Even though this gave rise to different interpretations and possible actions, one of the most dominant effects has been the emphasis on freedom of choice. The shift from a view of education as a public good to a private good has given rise to an extensive market orientation and a tendency towards greater segregation (Englund 1994; NAE 2012b; Rönnberg 2011). Furthermore, following the introduction of the goal- and result-oriented educational system in the early 1990 s, there has been a visible shift in policy discussion from an emphasis on goals to one on results (Morawski 2010; Wahlström 2009). When the quality concept was explicitly introduced in Swedish education policy in 1997, only a few years had passed since the extensive reforms of the early 1990s (Bergh 2010). From 2006 and onwards another reform wave was investigated and implemented. While the policy discussion of the early 1990s emphasised 'bildung', democracy and an understanding of knowledge as constructed by people in interaction, this was replaced in the second reform wave by an emphasis on goal attainment in combination with a significantly strengthened national control system.

Earlier research has pointed out how Swedish education policy has changed from political and ideological standpoints to more one-sided discussions about results, often expressed in terms of goal attainment (Arneback and Bergh 2010; Segerholm 2009). It is also apparent that international standards-based curriculum reforms have had a considerable influence on Swedish education in recent years, although there has been no problematisation of or official debate about this (Sundberg and Wahlström 2012). With an increased focus on educational results, national educational politicians have decided on a number of structural changes that have transformed the design of the educational system. Among other things, as part of the strengthened national control system an increased number of tests, inspections and a 
new grading system have been introduced. Altogether, this means that in recent decades there has been an extensive restructuring of the Swedish school system, with an intensified coordination of different centralisation initiatives that are parallel to and sometimes independent of one another in and between the different international and national arenas (Nordin 2012).

How was the quality concept able to challenge and partly marginalise the earlier Swedish education tradition within such a short period? Besides the influence from international trends, such as New Public Management and Total Quality Management (TQM), it is important to bear in mind that a series of events in the national context also contributed to this (Bergh 2010). Although the introduction of the quality concept in 1997 can be seen as a starting point for quality thinking, the question of quality was not new at the governmental level. Already in the early 1980s, the government was made aware of the problems facing domestic-industrial companies struggling to keep up with the international competition and in the late $1980 \mathrm{~s}$, quality problems observed in other countries were reported in the international education cooperation. Moreover, soon after the extensive reforms of the early 1990s, strong pressure was put on the government, both in the political debate and through the reporting of various shortcomings, which made it necessary to demonstrate political renewal and the ability to act in order to increase confidence in the state and education (Nytell 2006). The quality idea, with its positive and flexible meaning that was also associated with desirable success models, then became the dominant political strategy behind which the business community and the state could unite. The fact that the quality concept soon became paired with the concept of goal achievement, and over time increasingly with results, can also be understood in relation to the goal- and result-oriented steering system (Bergh 2010). Although both the government and the National Agency for Education (NAE) emphasised goals and goal interpretation for a great deal of the 1990s, the difficulty of following up overarching goals was known and discussed before the system was introduced (cf. Wahlström 2009). However, in the new steering system that was introduced in the early 1990s, instruments for the reporting of results were not provided for, but were introduced in connection with the requirement for written quality reports. Thus, the way in which the quality concept successively takes shape in education is closely linked with efforts to improve the goal- and result-oriented steering system.

Following the policy changes, paradoxical consequences for the teaching profession have been reported from different countries. From a Norwegian and Swedish context, Solbrekke and Englund $(2011,847)$ conclude that mechanisms of accountability seem to be 'triumphing' over professional responsibility in today's governance system. Similar conclusions are reported from Australia, where two competing teacher discourses were identified in the early 2000s: the so-called democratic professionalism emerging from the profession itself and the managerialist professionalism reinforced by policies with an emphasis on accountability and effectiveness (Sachs 2001). Two years later, Stephen Ball (2003, 216) notes that: 'One key aspect of the current educational reform movement may be seen as struggles over the control of the field of judgement and its values'. In 2013, it is reported that the reforms will further move English teachers from an occupational profession to an organisational profession (Page 2013).

Altogether, in this development it is important to analyse the consequences that follow for the quality work that is supposed to take place at local level, especially as the Swedish Government states that the education assignment is still the same as it 
was formulated in the early 1990s (Bill 2008/09:87). By doing this, the intention is to contribute knowledge about how internationally influenced policies are interpreted and translated by national policy actors and to discuss the consequences that might follow for those doing the work at local level.

\section{Theoretical concepts and methodological approach}

Two sets of theoretical concepts are used for the analysis. First, management of placement and management of expectation are used as broad paradigms of approaches to management in order to demonstrate how the expectations for local quality work expressed in Swedish education policy documents have changed over time. Then, to further grapple with the conceptual complexities of these two; the analysis also makes use of the concepts autonomy and control.

As a way of describing the stepped transition towards what Hopmann (2008) calls the age of accountability, in which student achievement has become the prime indicator of the quality of schooling, he uses the concepts: management of placement and management of expectation. The first, management of placement, is used to characterise the development of the modern state, where schools, hospitals, prisons, etc. are taken care of by institutions run by professionals with specific training in how to deal with so-called ill-defined problems. The legitimacy of the whole placement strategy relied on its ability to cover new ill-defined problems and the internal distribution of resources, and the evaluation of outcomes were mostly left to the professionals themselves. However, with 'the crisis of the welfare state' and a growing mistrust and anxiety as to whether this strategy would be sustainable, it has been successively replaced by a management of expectation strategy (423). In this, the attempt is to transform ill-defined problems into better defined expectations of what can be achieved by whom with the resources that are available. A central point in this strategy is that only those outcomes that meet the predefined expectations are considered successful; something that, for example, could explain the status that PISA is now given in many countries. In contrast to management of expectation, with its 'ever-changing fabric of expectations' and the 'simple fact that accountability needs something which can be counted, or where it is at least possible to measure the distance between expectations and results' (425), the management of placement strategy had

no external public evaluation of the quality of the services provided, except for extraordinary cases of failure ... Accordingly, good instruction was not defined primarily by its measurable outcomes, but rather by the professional judgement of the adequacy of what was done. (Hopmann 2008, 424)

Besides inspiration from Hopmann (2008), the study also makes use of Cribb's and Gewirtz's (2007) work on autonomy and control. As they point out: 'In making assessments about the value of different patterns of autonomy-control it is necessary to grapple with conceptual, empirical and normative complexities' (212). By doing this, I hope to contribute knowledge that avoids 'the seemingly widespread - and usually unspoken - normative presumption that autonomy is good and control is bad and to open up space for the possibility of richer debates about the value of different forms of and balances between autonomy and control' (203).

The empirical analysis described in the next part of the article is structured under four headings, each with a focus on a different time period. Under each heading the 
analysis is conducted in two steps. In the first step, the expectations on local quality work as expressed in Swedish education policy documents over the last two decades are characterised with the support of the management of placement and management of expectation concepts. In the second step, each time period is analysed from a specific interest in the relation between different forms of autonomy and control. With inspiration from Cribb and Gewirtz (2007), this second step is guided by three questions that are successively answered throughout the analysis: Whose autonomy is in question? Autonomy/control over what? Who are the agents of control and how is their agency exercised?

\section{Changing expectations in the local work with quality}

As will now be demonstrated, the last two decades of changing expectations in the local work with quality can broadly be described as a successive shift from a management of placement strategy to a management of expectation strategy. An initial and very general characterisation is that on the one hand there seems to be a clear parallel between the management of placement strategy and an emphasis on teacher autonomy, and on the other between the management of expectation strategy and the development of the strengthened national control system. However, to enhance further understanding, each time period is followed by an analysis of the relation between different forms of autonomy and control supported by the three questions indicated above.

\section{Late 1980s and early 90s: trust in teachers perspectives on knowledge, learning and teaching}

In the early 1990s, which can be characterised as dominated by a management of placement strategy, the question of how teaching was going to be conducted was primarily a matter for teachers to decide. This was also a central point of departure in the education reforms, where teachers were given increased responsibilities for the selection of content and decisions about how knowledge should be organised.

Teachers' work requires perspectives on knowledge, learning and teaching, and how these are addressed in the classroom. Such activities cannot be governed by national regulations. Rather, it is the interplay between teachers' theoretical knowledge and the practical activities undertaken that is decisive. (Bill 1992/93:220, 18)

This citation illustrates that at that time the government's vision did not only relate to an earlier political tradition, but also to current pedagogical ideas about learning, development and teaching (cf. Håkansson and Sundberg 2012). However, at the same time as teachers' autonomy (although the term was not explicitly used) was highlighted as a prerequisite for the exercise of teachers' professional expertise other arguments indicated that this standpoint was challenged. In the years around the early 1990s, the concept of quality had still not made its mark on Swedish education, although it was not a totally unfamiliar issue. When in the late $1980 \mathrm{~s}$, the government reported on tendencies from the international education cooperation: it was pointed out that other countries were becoming concerned about the lack of quality in schools, that school was not good enough to drive the economic development and that there was an increased interest in evaluation (Bill 1988/89:100). Nevertheless, from the problems reported internationally, the government at that time led by the Social Democrats, concludes ${ }^{1}$ : 
What is particularly interesting in the light of the ambitions for social equality outlined in the educational reforms .... is that the standard of schooling in Sweden is not only high ... but is also even ... The differences between different schools in our country are less than those in any other participating country. (Bill 1988/89:100, 9)

Despite this, only a few years later the government, now led by a right-wing coalition, states that there is a well-established correlation between the quality of education, knowledge and economic growth (Bill 1992/93:220). As quality is a key competitive factor, the government argues that Swedish schools must be among the best in the world: 'This is an inescapable fact in spite of all the reservations that can be made about the difficulties of measuring a school's quality and determining the relevance of different kinds of knowledge' (10). Following this, the government asserts that new demands will be made on teachers, school leaders and schools, demands that may at times seem contradictory.

\section{Late 1980s and early 1990s: interpreted in terms of autonomy and control}

Whose autonomy was in question in the late 1980s and early 1990s? An initial answer is that autonomy was seen as a precondition for teachers' professional expertise. But, and perhaps more importantly, autonomy was also given the purpose of shaping a good learning situation for the pupils. In this way, teachers' autonomy can be seen as a goal in itself and also as a means for an education that should meet individual pupils' different needs for autonomy. Thus, the question of autonomy/ control over what can be understood in terms of complex and qualitative goals being placed at the local level to be interpreted and dealt with. That this was something to protect and was at the same time challenged is clear from the arguments put forward at the national policy level when the government (since 1994 again led by the Social Democrats) in 1997 announced that actions must be taken to improve and secure quality at all levels of the education system (Skr 1996/97:112). Following this, two new steering instruments were introduced: local quality reports and national quality reviews.

\section{Late 1990s: introduction of the quality concept - emphasis on reporting quality}

With the new quality reports, the government expected to solve the problems observed at local level by conducting follow-ups and evaluations. One explanation as to why this has been problematic is that local civil servants and politicians are familiar with the complexities and thereby see the difficulty of making fair descriptions and assessments. This, the government concludes, is in itself an important argument as to why each level needs to be responsible for its own quality work: 'Otherwise there is a danger that others with much less insight into the activities will pass judgement' (Skr 1996/97:112, 100).

The qualities that the government expected to improve in 1997 can be understood both in relation to the earlier social equality tradition and the challenging expectations of making Sweden more competitive in a globalised world. An example of the first is the argument in which the evaluative role of municipalities is pointed out as an important complement to the control conducted through the new grading system. The municipalities are particularly encouraged to bear goals, such as justice and democracy in mind. 
Such an evaluation must take account of basic goals like quality and equivalence in the education. Without quality equivalence has no substance, and without equivalence the quality discussion leads away from the goals of justice and democracy. Evaluations must ensure that students receive an equivalent education with the quality stated in the goals. (Skr 1996/97:112, 8)

What is noteworthy here is the general emphasis on goals and more specifically the goals of justice and democracy. The expectations are also directed at the local level, as it is there that the effects of segregation due to the freedom of choice reform can be observed. However, besides those expectations, which can be understood as expressions of a management of placement strategy, there are also expectations of reporting and improving goal attainment, which can be understood in relation to the new transformation according to the management of expectation strategy.

This tension is also reflected when the $\operatorname{NAE}^{2}$ (1999a) publishes its first general guidelines for quality reports. In the introductory lines it is made clear that the requirement for written reports does not mean that schools and local authorities impose new tasks, 'but only that the reporting of the follow ups and evaluations, which is already obligatory ... should now be made more clearly than before' (3). It is also emphasised that "national goals are open so that local circumstances and conditions can be expressed when the goals are formulated locally' (7). So, on the one hand there is an emphasis on the local work with school development through what is called participatory goal setting, while on the other 'new' expectations give signals that the outcome of the education must now be reported more clearly than before. Besides the 'internal' motives of giving the teaching staff a joint picture as the starting point for development-oriented activities, there are also expectations that the quality of education will be made visible to pupils, parents and other stakeholders, as well as to local and national school authorities.

\section{Late 1990s: interpreted in terms of autonomy and control}

A first conclusion that can be drawn from the way the quality concept was introduced in 1997 is that the international pressure on evaluations had become a reality that the national education policy actors could not ignore. Another conclusion is that several of the arguments for how to solve this new situation followed the earlier management of placement strategy, with an emphasis on local autonomy. Examples of this are that national goals are open so that local circumstances and conditions can be expressed and that local actors see the complexities and difficulties in making fair descriptions, which is presented as an important argument as to why each level should be responsible for its own quality work. In addition to these arguments for local autonomy, the analysis shows that this was clearly challenged, something that becomes even more obvious in the following years.

\section{Around the year 2000: a challenging period with demands for new solutions and actions}

It becomes clear from how quality is discussed in texts from NAE around the year 2000 that the introduction of the quality concept challenges the division of responsibility between different actors in the school system and makes demands for new solutions. In 1999, NAE (1999b) discusses the challenge set by the new national quality reviews to value schools in qualitative terms. This had not been done prior 
to 1999 because the then standpoint was that an assessment of quality was the responsibility of each individual school and its local authority.

What we now face is a break from this position in the sense that we, through education inspectors, should express valuations on a wider scale ... The requirement for quality reviews actually means that the government has instructed the National Agency for Education to make (a certain kind of) assessments at school and local authority levels.

(NAE 1999b, 12)

NAE also discusses the possibility of using TQM at the local educational level, but ends this discussion by concluding that 'new formulas for quality' will probably be developed that will not be based on industrial development, but will be more suited to education (NAE 1998a, 36). When the question of preconfigured quality models is returned to in later reports, NAE indicates that it has experienced via those municipalities that have acceded to special systems or models, that the character of the process has become one of control, rather than development and that quantitative, rather than qualitative data are prioritised (Bergh 2010).

However, at the same time as the explicit use of the concepts 'quality work' and 'quality reports' increases, the argumentation changes character. This also becomes visible in relation to discussions about follow-ups and evaluations. The earlier discussions about a school's own development needs and the pedagogical aspects of management by goals are now more related to governing performed by the local authorities. A typical illustrative comment is when NAE (1998b) writes that although interesting things are happening in many classrooms and schools, they are too easy to criticise because they are not documented. One hope is, therefore, that quality reports will contribute to schools describing their activities to others in a much better way. However, when the focus moves to the municipal level, a discrepancy arises between the municipal vision and everyday school life. As NAE formulates it, the development of the education system seems to 'race along on paper but accelerate slowly in reality' $(2003,48-49)$. This comment can be used as an example of how the social understanding of education changes from the previous management of placement strategy to the management of expectation strategy.

The year 2002 marks a clear break in the political rhetoric on quality because now the government declares the need to intensify national efforts, speed up development and raise the quality of education (Bergh 2010). The message that action must now be taken to remedy deficiencies that prevent goal attainment is expressed even more clearly in the government's quality programme published in the following year (Government Offices 2003). In this programme, democratic motives are no longer mentioned, but have been replaced by an emphasis on individualisation and the need to develop straightforward information and quality control.

The quality reports will now have clearer rules and be further developed, so that they in an easily accessible and comparable way show how the school achieves the national goals and what steps need to be taken to overcome possible shortcomings. (Government Offices 2003, 10)

It is worth noting that the dominant political expectation from 2002 that 'Sweden should be a leading knowledge nation' (Government Offices 2003, 2), is both in time and intention close to the Lisbon Strategy from 2000 in which the EU formulated the need for Europe to become the most competitive and dynamic knowledgebased economy in the world (cf. Grek and Lawn 2009). 
When a few years later NAE (2006) replaces the first version of the guidelines for quality reports with a later version, this is in line with the changed political rhetoric. As a consequence, previous arguments about the importance of local goal interpretations are no longer mentioned. Instead, the central expectation is that the guidelines 'should help to strengthen a systematic quality work and thereby improve the schools' work and goal attainment' (5). Compared to the previous guidelines, the range of the text increases approximately three times, new requirements are added and the importance of participation and involvement is emphasised. In addition, it is stated that the quality report should be used to provide information about school activities and goal attainment. The increased use of the concepts systematic quality work, improvement and goal attainment gives a good indication of what the dominating expectations are, now formulated and specified in what can be characterised as a management of expectation strategy.

\section{Around the year 2000: interpreted in terms of autonomy and control}

In the shift from the management of placement strategy to the management of expectation strategy, autonomy could no longer be given as a trust because what happened at the local level had to be transparent to others. This is also an answer to the question of who the agents of control are, and how their agency is exercised. The question is now no longer if the quality of schools can be measured, but rather how this can be done and by whom? The expectations formulated in the late 1990s that local actors should be able to deal with this were soon abandoned. As NAE concludes in a report from one of the first national quality reviews:

schools have often traditionally measured the level of input and judged that as equal to the result achieved. The inspectors have encountered this way of measuring input, rather than goal attainment and a strong focus on the process, in many places [...] The review team can conclude that we are only just beginning to develop uniform assessment criteria and a common language that facilitate the reporting of quality. (NAE 2000, 55)

Several conclusions can be drawn from the analysis so far. First, that the lack of language for meeting the new demands for transparency changed the relation between the earlier given teacher autonomy and the exercise of control. Second, that the changes in actors and language from the local level to the national offered new 'truths' about what was 'really' going on in Swedish schools, such as the development of the education system seeming to 'race along on paper but accelerate slowly in reality' (NAE 2003, 48-49). A third conclusion follows on from this, namely that the content of the quality argued for has successively changed from an emphasis on qualitative and complex goals to a more one-sided emphasis on goal attainment and systematics.

\section{6 and onwards: from political rhetoric to structural transformation}

Starting in 2006, the Swedish education system is extensively restructured in accordance with the linguistic change of a few years earlier. The dominant expectation is now that Sweden will be a successful country and that Swedish schools will achieve significantly better results. According to the government (2006-2014 led by a rightwing coalition), this requires 'an education system that has the capacity to see every 
pupil's potential' (Bill 2008/09:87, 7). Such a system presupposes a chain of interrelated links: 'The state is presumed to formulate goals in terms of steering documents curricula and syllabi that "speak to" the teachers in a clear and effective way. The teachers in turn are supposed to be able to read the state's intentions in an insightful way' (SOU 2007:28, 166). From these starting points, the education system as a whole is restructured and implemented within a period of just a few years.

Altogether, this means that the conditions for local work with quality change. One of the most visible changes is that the requirement for obligatory quality reports from 1997 are removed (SFS 2010:800). At the same time, the quality concept is given a strengthened juridical position, in that the concepts of quality and influence are now brought together in the fourth chapter of the new Education Act. According to the government, the reason for bringing these two concepts together in a joint chapter is that there are several similarities between them and also that 'the government wants to stress the importance of these features in a goal- and result-oriented system' (Bill 2009/10:165, 302). In addition to providing municipalities and national school authorities with information, there are now expectations that by gaining access to important information pupils and parents will become more involved, and thereby be in a better position to make choices and influence the development. The ultimate purpose is increased quality and improved goal attainment. With these starting points the government states that:

\begin{abstract}
National equivalence in a decentralized system presupposes that the state sets national goals and systematically follows up and checks that the goals have been achieved and that a systematic quality work is developed at the local level [...] The government's more stringent requirements for more frequent and systematic evaluations of the school's quality, e.g. by an extension of inspection activities and more national tests, means that there is no longer the same need for a detailed regulation of how the quality work should be conducted locally. (Bill 2009/10:165, 303)
\end{abstract}

That there is now a sharper national system for controlling the quality of schools is also the argument put forward by the government in response to the referral bodies that have expressed concerns about local quality work deteriorating if the demand for written reports is removed. Despite the decision to remove the regulation, there are still demands for local authorities and schools to document their systematic quality work. Even though the government chooses not to specify any detailed regulation of content and structure, it is nevertheless stated that it is reasonable for the documentation to include information about results and goal attainment, as well as an analysis of areas for improvement and decisions on planned actions. Concrete examples of what the local authority is expected to do include an analysis of the variations between schools' results and attainments and the equivalence ${ }^{3}$ in the schools' assessments and grading. The local authority is also expected to act if there are complaints, correct deficiencies and be responsible for the availability of a systematic and accessible documentation of results and quality work.

Based on the given examples of what this documentation should include, it can be concluded that it primarily consists of quantitative data and subject-oriented results, such as 'information at school level about e.g. the teacher ratio, grades, results of national tests and inspection reports, which allows a comparison between different schools' (Bill 2009/10:165, 305). Goal attainment at school level is also emphasised: 'That teachers and preschool teachers systematically develop their teaching with a view improving goal attainment is central to an enhancement of quality in preschools and schools' (308). The government also refers to the proposal 
put forward by the Inspection Commission (SOU 2007:101) that before an inspection, schools should complete a self-evaluation and states that the investigator's intentions for quality work at school level are well in line with the government's thinking.

The Education Inspectorate's review assignment should be based on a self-evaluation where the local school authority and the principal report the quality of the education they are responsible for. A self-valuation could consist of two parts. One could be a declaration of compliance according to the rules. The second could contain assessments of the work with the knowledge assignment. (SOU 2007:101, 14)

A conclusion that can be drawn from this citation is that the information asked for constitutes a limited part of the education assignment as a whole, as formulated in the national curricula. Although the knowledge assignment and legal compliance with the rules are highlighted, other goals and values are not mentioned, such as the earlier emphasised democracy and 'bildung' concepts or the discussions about a dynamic knowledge concept with room for creative, aesthetic and ethical dimensions (cf. Bill 1992/93:220). There is, thus, a clear gap between the earlier education vision and the now dominating expectation of improving the results in order to make Sweden a successful country.

The shift from an emphasis on goals to an emphasis on results is thus reflected in the use of the quality concept and also in how expectations concerning local work with quality are formulated. As a consequence, the systemic approach with a sharper national system for controlling the quality of schools indicates that the decentralisation intentions of the 1990s to develop local schools have been replaced by national efforts to build a goal- and result-oriented steering system. These expectations are far removed from those for local participation in goal setting in combination with evaluations made by competent pedagogical staff formulated two decades earlier.

\section{6 and onwards: interpreted in terms of autonomy and control}

Following the same three questions asked in the previous sections, the first is: Whose autonomy is in question after the linguistic break in 2002 and the structural transformation that followed from 2006 and onwards? From the earlier emphasis on local autonomy, the arguments are now of a completely different character. In the name of equivalence it is stated that the goals must be written down so that they are not wide open to different interpretations (SOU 2007:28). Furthermore, the control system is strengthened at all levels in order to improve equivalence, guarantee legal safeguards and raise goal attainment. One way of interpreting this is to say that teachers' autonomy has been reduced in order to improve the conditions for and rights of each pupil. However, this is done in very specific ways. First, it has to do with the right to be safe and through the early discovery of needs and shortcomings to receive an education, where each pupil reaches the stated goals. Second, it gives pupils the formal right to be involved in the quality work, and thus to express ideas about and experiences of their education. According to NAE's $(2012 \mathrm{a}, 18)$ guidelines for systematic quality work: 'Children and pupils are important resources in the work to plan, follow up and develop school activities'. This, NAE argues, will also 'increase the possibility of obtaining a good basis for the joint analysis of goal attainment and development needs' (2012a). 
As a consequence, the question of autonomy/control over what can be answered using the same central concepts. For example, this is reflected when the reason for quality work is formulated in the third version of NAE's guidelines, namely that: 'the national goals for the education shall be achieved. The purpose is also to enable involvement in and dialogue about the goal attainment and the reasons for possible shortcomings' $(2012 \mathrm{a}, 12)$. One way of interpreting this is that the guidelines can be understood as a general structure provided by the state, whereas the question of content is the teachers' responsibility. Yet, the dominance of the knowledge concept mentioned more than 30 times compared to the concept of democracy that is not mentioned at all - gives an indication of what the state expects.

Finally, the third question: Who are the agents of control, and how is their agency exercised? Whereas in the 1990s, a good education was expected to be achieved by the interplay between teachers' theoretical knowledge and the practical activities carried out in school, the expectation almost two decades later is to develop an 'education system that has the capacity to see the potential in every pupil' (Bill 2008/09:87, 7). In such a system, the state has a central position from which to exercise control. In addition to the curricula documents, with their revised clear goals and knowledge requirements (SOU 2007:28), the state exercises control by an extension of national tests and significantly strengthened inspections. Moreover, in such as a system, a good teacher is one who works systematically, which primarily means in an insightful way and reading the curricula that has been formulated with the intention of 'speaking to' teachers in a clear and effective way (SOU 2007:28). It also means that teachers are supposed to plan, conduct and follow-up their teaching, which, in combination with the systematic quality work, should be done according to the structures and advice provided in the national guidelines (NAE 2011; NAE 2012a).

Compared to the arguments for autonomy, which focus on local actors and especially teachers, the arguments put forward to legitimise a strengthened state control are quite different in character. While national policy texts from the late 1980s and onwards signal hesitation about the possibility of measuring and evaluating quality, this is something that successively changes. When in 2010, the government states that 'an equivalent education requires that legal safeguards and quality in schools can be assured' and that for the sake of the students it is of 'the utmost importance to observe and draw attention to shortcomings early on', these arguments are put forward as having unchallenged status (Bill 2009/10:165, 538). The language used with central concepts, such as equivalent education, legal safeguards, assuring quality and drawing attention to shortcomings, reflects the argumentation that has led to a shift in the balance between teacher autonomy and state control (for an overview of the changes during the last two decades, see Figure 1).

As a consequence of this development, it is no longer enough for teachers to simply do their job based on their own professional judgements. They must also regularly communicate what they do by using concepts that do not have their origins in teachers' locally based professional knowledge and experience. The over-riding frame provided by the state for the work at local level is the systematic quality work, in which local authorities, parents and pupils are also highlighted as important actors. However, it can be asked whether in this system each pupil is a goal in itself or a means for increased goal attainment in order to make Sweden more internationally competitive. 


\begin{tabular}{|l|l|l|}
\hline \multicolumn{3}{|c|}{ Changing expectations in the local work with quality } \\
\hline \multicolumn{1}{|c|}{ Management of placement } & \multicolumn{1}{c|}{ Management of expectation } \\
\hline $\begin{array}{l}\text { Whose } \\
\text { autonomy is in } \\
\text { question? }\end{array}$ & $\begin{array}{l}\text { Autonomy is a precondition for } \\
\text { teachers' professional expertise and to } \\
\text { enable an education that meets } \\
\text { individual pupils' different needs. }\end{array}$ & $\begin{array}{l}\text { Teachers' autonomy is reduced in order to } \\
\text { improve national equivalence, guarantee } \\
\text { legal safeguards and raise goal attainment. }\end{array}$ \\
\hline $\begin{array}{l}\text { Autonomy/ } \\
\text { control over } \\
\text { what? }\end{array}$ & $\begin{array}{l}\text { Complex and qualitative goals are } \\
\text { placed at the local level to be } \\
\text { interpreted and dealt with by teachers. }\end{array}$ & $\begin{array}{l}\text { Clear goals and knowledge demands should } \\
\text { enable involvement and dialogue about goal } \\
\text { attainment and the reasons for possible } \\
\text { shortcomings. }\end{array}$ \\
\hline $\begin{array}{l}\text { Who are the } \\
\text { agents of } \\
\text { control and } \\
\text { how is their } \\
\text { agency } \\
\text { exercised? }\end{array}$ & $\begin{array}{l}\text { Each level is responsible for its own } \\
\text { quality work. A good education can be } \\
\text { achieved by the interplay between } \\
\text { teachers' theoretical knowledge and } \\
\text { the practical activities undertaken. }\end{array}$ & $\begin{array}{l}\text { A system with strengthened national control } \\
\text { in which teachers plan, conduct and follow } \\
\text { up their teaching supported by the } \\
\text { structures and advice provided in the } \\
\text { national guidelines for systematic quality } \\
\text { work. }\end{array}$ \\
\hline
\end{tabular}

Figure 1. An overview of the changing expectations in local work with quality from the 1990 s and onwards, structured with support from the theoretical concepts used in the article.

\section{Discussion - quality work and the implications for teachers' practices}

In this section I return to the research question formulated earlier in the article: How can local systematic quality work be understood in an age of accountability and what are the implications for teachers' practices? From the analysis of Swedish authoritative texts conducted in the study, conclusions can be drawn that hopefully also provide insights for future research on how policy is enacted at different levels and educational contexts (cf. Braun, Maguire, and Ball 2010).

A first implication is that there has been a significant change in the language used. This could also explain why the question of what constitutes good education has become so much more difficult to pose (cf. Biesta 2010). With the language that characterises the age of accountability, the question of which education is desirable is not asked (cf. Lundahl and Waldow 2009). As Hopmann (2008) formulates it, in the name of goal attainment, the focus is instead on the restructuring of public institutions, the retooling of legitimation and control patterns, as well as pressure on systems and actors to take a reflexive stance towards themselves and responsibility for their own 'well-being'. This not only means a new language and ways of structuring education, but also fundamentally challenges teacher's professionalism and the conditions for pupils' learning. In this sense, local quality work in the Swedish context can be seen as a symbol for a changed social perception of education in the age of accountability (cf. Bergh 2010). Although the government states that the education assignment is still the same (Bill 2008/09:87), i.e. as it was formulated two decades earlier, this is not a starting point that has been seriously taken into account in the last decade's extensive restructuring of the Swedish school system. From the UK it has already been reported 'that the systemic approach adopted by policy-makers may be contributing to an erosion of educational quality and placing potentially 
damaging expectations on children' (Bates 2013, 38). Despite the social, political and cultural differences between the countries, this conclusion may also be valid for Swedish education. It is, therefore, important to pay attention to and conduct further studies of the consequences of this governing in different national and local educational contexts.

The next implication follows on from this, namely that the content of education has been recontextualised from one level of responsibility to another. In the 1990s, when knowledge was seen to be constructed by people in interaction, the choice of content and decisions about how this should be organised were placed at the local level to be dealt with by autonomous teachers. When the language changed, according to the management of expectation strategy, the former knowledge concept was replaced by the new ideal of clear goals and knowledge demands. As a consequence, complex and qualitative content has become a non-issue in the policy rhetoric, at the same time as it is expected to be dealt with at the local level. Thus, a critical question is what happens if the dominating policy language also becomes the norm for what quality in education means. As Braun et al. put it, 'schools and teachers are expected to be familiar with, and able to implement, multiple (and sometimes contradictory) policies that are planned for them by others, while they are held accountable for this task' $(2010,547)$. So, a possible conclusion is that in order to meet paradoxical policy expectations, teachers must be able to speak at least two different languages and translate between them, i.e. the dominant policy language and a more professional language that relates to all the goals in the curriculum document. Besides being familiar with policies per se, it means that teachers must also be familiar with the normative language that holds them in place. As Quentin Skinner argues, while we are embedded in practices and constrained by them, 'it is always open to us to employ the resources of our language to undermine as well as to underpin those practices' $(2002,7)$. In this way, the power of language has the potential to gain control over the field of judgement and its values, and thereby challenge linguistically constructed policy truths about what is 'really' going on (cf. Ball 2003).

Finally, a third implication puts the spotlight on the relation between autonomy and control. As Cribb and Gewirtz $(2007,212)$ argue, 'teachers need both autonomy and control and that what is at issue is really the balance between these closely linked ideas and the different forms that they can take in combination'. One way of understanding the Swedish case is to say that national education policy has created an education for a system, rather than a system for education (cf. Bergh 2010). While great emphasis has been put on making the system controllable, for example, through national school inspections (cf. Rönnberg 2011), there has been a very limited focus on pedagogical aspects. As a consequence, the skills required by teachers have been juridically and structurally oriented. Although this can be criticised, supporting structures, juridical skills and a systematic way of working are important in order to create conditions for a good education. However, problems could arise when the conditions create limits or even become counter-productive in relation to visions of what is educationally desirable. In the management of expectation strategy there is no content related educational vision, but rather a one-sided emphasis on goal attainment and building structures for control. Therefore, if local systematic quality work is to facilitate good education as part of a system for education, it must take its starting point in an ongoing discussion of what is meant by 'good education' and how different forms of autonomy and control can best be combined. 


\section{Acknowledgements}

This article was supported by the Faculty Board of Humanities and Social Sciences at Örebro University and the Faculty of Educational Sciences at Uppsala University. The author acknowledges the support of researchers at the Centre for Public Policy Research (CPPR) at King's College London, the Education and Democracy research group at Örebro University and the Studies in Educational Policy and Educational Philosophy (STEP) research group at Uppsala University.

\section{Notes}

1. During the studied period, the Swedish Government was alternately led by the Social Democrats and a right-wing coalition consisting of the Moderates, the Centre Party, the Christian Democrats and the Liberals: 1982-1991 Social Democrats, 1991-1994 rightwing coalition, 1994-2006 Social Democrats and 2006-2014 right-wing coalition.

2. The National Agency for Education is hereafter shortened to NAE.

3. Equivalence has been a central concept in Swedish educational policy for several decades (Englund and Quennerstedt 2008). Even though different interpretations of quality and equivalence could be in tension, also the use of equivalence has changed over time. In the policy texts of the twenty-first century, equivalence has been given the more limited meaning of goal attainment or, as in the above sentence, in relation to expectations about equivalent assessments.

\section{Notes on contributor}

Andreas Bergh's research interests centre on education policy, conceptual uses and curriculum theory and in a recent project on the use of prevention and promotion programmes in schools. $\mathrm{He}$ is a member of the Education and Democracy research group at Örebro University and the Studies in Educational Policy and Educational Philosophy (STEP) research group at Uppsala University.

\section{References}

Arneback, E., and A. Bergh. 2010. "Den paketerade valfriheten - Om Framtidsvägen för den svenska gymnasieskolan." [The Pre-packaged Freedom of Choice - On the Future of Swedish Upper Secondary School.] Nordic Studies in Education 30 (2): 117-131.

Ball, S. J. 2003. "The Teacher's Soul and the Terrors of Performativity." Journal of Educational Policy 18 (2): 215-228.

Bates, A. 2013. "Transcending Systems Thinking in Education Reform: Implications for Policy-makers and School Leaders." Journal of Educational Policy 28 (1): 38-54.

Bergh, A. 2010. Vad gör kvalitet med utbildning? Om kvalitetsbegreppets skilda innebörder och dess konsekvenser för utbildning [What does Quality do to Education? Different Meanings of the Concept of Quality and their Consequences for Education], 29. Örebro: Örebro Studies in Education.

Bergh, A. 2011. "Why Quality in Education - And What Quality?" Education Inquiry 2 (4): 709-723.

Biesta, G. 2010. Good Education in an Age of Measurement: Ethics, Politics, Democracy. Boulder, CO: Paradigm Publishers.

Bill 1988/89:100. Regeringens proposition med förslag till statsbudget för budgetåret 1989/90. Bilaga 10 [The Government's Bill with Proposition on State Budget 1989/90. Appendix 10].

Bill 1992/93:220. En ny läroplan för grundskolan och ett nytt betygssystem för grundskolan, sameskolan, specialskolan och den obligatoriska särskolan [A New Curriculum for Elementary School and a New Grading System for Elementary School, Sami-School, Special School and Compulsory School for the Intellectually Challenged].

Bill 2008/09:87. Tydligare mål och kunskapskrav - nya läroplaner för skolan [Clearaer Goals and Knowledge Demands - New Curricula for School]. 
Bill 2009/10:165. Den nya skollagen - för kunskap, valfrihet och trygghet [The New Education Act - For Knowledge, Freedom of Choice and Safety].

Braun, A., M. Maguire, and S. J. Ball. 2010. "Policy Enactments in the UK Secondary School: Examining Policy, Practice and School Positioning." Journal of Educational Policy 25 (4): 547-560.

Cribb, A., and S. Gewirtz. 2007. "Unpacking Autonomy and Control in Education: Some Conceptual and Normative Groundwork for a Comparative Analysis." European Educational Research Journal 6 (3): 203-213.

Englund, T. 1994. "Education as a Citizenship Right - A Concept in Transition: Sweden Related to Other Western Democracies and Political Philosophy." Journal of Curriculum Studies 26 (4): 383-399.

Englund, T., and A. Quennerstedt. 2008. "Linking Curriculum Theory and Linguistics: The Performative Use of Equivalence as an Educational Policy Concept." Journal of Curriculum Studies 40 (6): 713-724.

Government Offices. 2003. Alla skolor ska vara bra skolor - regeringens kvalitetsprogram för skolan [All Schools shall be Good Schools - The Government's Quality Program for Education]. Stockholm: Utbildningsdepartementet [Ministry of Education].

Grek, S., and M. Lawn. 2009. "A Short History of Europeanizing Education. The New Political Work of Calculating the Future." European Education 41 (1): 32-54.

Håkansson, J., and D. Sundberg. 2012. Utmärkt undervisning. Framgångsfaktorer i svensk och internationell belysning [Excellent Teaching. Success Factors in a Swedish and International Perspective]. Stockholm: Natur \& Kultur.

Hopmann, S. T. 2008. "No Child, no School, no State Left Behind: Schooling in the Age of Accountability." Journal of Curriculum Studies 40 (4): 417-456.

Hopmann, S. T. 2013. "The End of Schooling as We Know it?" Journal of Curriculum Studies 45 (1): 1-3.

Journal of Education Policy 24 (2): 121-216. 2009. "Special Issue: Fabricating Quality: Data and the New Governance of Education."

Lundahl, L. 2002. "Sweden: Decentralization, Deregulation, Quasi-markets - And then what?" Journal of Education Policy 17 (6): 687-697.

Lundahl, C., and F. Waldow. 2009. "Standardisation and 'Quick Languages': The Shapeshifting of Standardised Measurement of Pupil Achievement in Sweden and Germany." Comparative Education 45 (3): 365-385.

Maguire, M. 2002. "Globalisation, Education Policy and the Teacher." International Studies in Sociology of Education 12 (3): 261-276.

Morawski J. 2010. Mellan frihet och kontroll. Om läroplanskonstruktioner $i$ svensk historia [Between Freedom and Control. Constructions of Curricula in Swedish Schools], 28. Örebro: Örebro Studies in Education.

NAE (National Agency for Education). 1998a. Kvalitetssäkring $i$ skolan. En rapport om kvalitet - begreppsanalys, TQM:s historia och dess användbarhet vid utvärdering av skolans kvalitet [Quality Assurance in School. A Report on Quality - Conceptual analysis, the History of TQM and its Usability for Evaluations of Quality in Schools]. Stockholm: Skolverket.

NAE (National Agency for Education). 1998b. Nationella kvalitetsgranskningar 1998. Rapport $n r 160$ [National Quality Reviews 1998. Report no 160]. Stockholm: Skolverket.

NAE (National Agency for Education). 1999a. Skolverkets allmänna råd om kvalitetsredovisning inom skolväsendet [The National Agency's General Guidelines for Quality Reports in the School System]. Stockholm: Skolverket.

NAE (National Agency for Education). 1999b. Vad menar vi? [What Do We mean?]. Dnr 99:382. Stockholm: Skolverket.

NAE (National Agency for Education). 2000. Nationella kvalitetsgranskningar 2000 [National Quality Reviews 2000]. Stockholm: Skolverket.

NAE (National Agency for Education). 2003. Nationella kvalitetsgranskningar 2001-2002. Lusten att lära - med fokus på matematik [National Quality Reviews 2001-2002. The Desire to Learn - With a Focus on Mathematics]. Stockholm: Skolverket.

NAE (National Agency for Education). 2006. Allmänna råd och kommenterar Kvalitetsredovisning [General Guidelines and Comments for Quality Reporting]. Stockholm: Skolverket. 
NAE (National Agency for Education). 2011. Skolverkets allmänna råd för planering och genomförande av undervisningen - för grundskolan, grundsärskolan, specialskolan och sameskolan [The National Agency's General Guidelines for the Planning and Conducting of Teaching - For Elementary Schools, Sami-Schools, Special Schools and Compulsory Schools for the Intellectually Challenged]. Stockholm: Skolverket.

NAE (National Agency for Education). 2012a. Allmänna råd med kommentarer om Systematiskt kvalitetsarbete - för skolväsendet [General Guidelines with Comments on Systematic Quality Work - For the School System]. Stockholm: Skolverket.

NAE (National Agency for Education). 2012b. Likvärdig utbildning i svensk grundskola? En kvantitativ analys av likvärdighet över tid [Educational Equity in the Swedish School System? A Quantitative Analysis of Equity over Time]. Stockholm: Skolverket.

Nordin, A. 2012. "Kunskapens politik - en studie av kunskapsdiskurser i svensk och europeisk utbildningspolicy" [The Politics of Knowledge - A Study of Knowledge Discourses in Swedish and European Education Policy]. Linnaeus University Dissertations No. 97, Linnéuniversitetet, Växjö.

Nytell, H. 2006. Från kvalitetsidé till kvalitetsregim. Om statlig styrning av skolan [From a Quality Idea to a Quality Regime. On State Governing of the School]. Uppsala: Acta Universitatis Upsaliensis. Uppsala Studies in Education, 114.

Ozga, J. 2009. "Governing Education through Data in England: From Regulation to Self-evaluation." Journal of Education Policy 24 (2): 149-162.

Page, D. 2013. "The Abolition of the General Teaching Council for England and the Future of Teacher Discipline." Journal of Education Policy 28 (2): 231-246.

Rönnberg, L. 2011. "Exploring the Intersection of Marketisation and Central State Control through Swedish National School Inspection.” Education Inquiry 2 (4): 689-707.

Sachs, J. 2001. "Teacher Professional Identity: Copmeting Discourses, Competing Outcomes." Journal of Education Policy 16 (2): 149-161.

Segerholm, C. 2009. "We are Doing Well on QAE': The Case of Sweden." Journal of Education Policy 24 (2): 195-209.

SFS 2010:800. Skollag [Education Act]. Stockholm: Utbildningsdepartementet [Ministry of Education].

Sivesind, S., J. van den Akker, and M. Rosenmund. 2012. "Editorial. The European Curriculum: Restructuring and Renewal." European Educational Research Journal 11 (3): 320-327.

Skinner, Q. 2002. Visions of Politics. Volume 1. Regarding Method. Cambridge: Cambridge University Press.

Skr 1996/97:112. Utvecklingsplan för förskola, skola och vuxenutbildning - kvalitet och likvärdighet [Development Plans för Preschools, Schools and Adult Education - Quality and Equivalence]. Stockholm: Utbildningsdepartementet [Ministry of Education].

Solbrekke, T. D., and T. Englund. 2011. "Bringing Professional Responsibility Back In." Studies in Higher Education 36 (7): 847-861.

SOU 2007:101. Tydlig och öppen. Förslag till en stärkt skolinspektion [Clear and Open. Proposal for a Strengthened School Inspection]. Stockholm: Fritzes.

SOU 2007:28. Tydliga mål och kunskapskrav i grundskolan [Clear Goals and Knowledge Requirements in Compulsory School]. Stockholm: Fritzes.

Sundberg, D., and N. Wahlström. 2012. "Standards-based Curricula in a Denationalised Conception of Education: The case of Sweden." European Educational Research Journal 11 (3): 342-356.

Wahlström, N. 2009. Mellan leverans och utbildning. Om lärande i en mål- och resultatstyrd skola [Between Delivery and Education. On Learning in a Goal- and Result-oriented School]. Göteborg: Daidalos. 